\title{
TINGKAT PENDIDIKAN, PEKERJAAN IBU, DAN KELENGKAPAN IMUNISASI PADA BAYI DI WILAYAH KERJA PUSKESMAS BASUKI RAHMAD KOTA BENGKULU
}

\section{Education Level, Mother's Work, and Immunization Completeness of Babies in Working Area of Basuki Rahmad Public Health Center Bengkulu}

\author{
Santoso Ujang Effendi ${ }^{1}$, Yusran Fauzi ${ }^{1}$, Winda Agustina $^{1}$ \\ ${ }^{1}$ Program Studi Kesehatan Masyarakat STIKES Tri Mandiri Sakti Bengkulu \\ Email:santos_ue@yahoo.com
}

\begin{abstract}
ABSTRAK
Penelitian ini dilatarbelakangi oleh masih adanya cakupan imunisasi yang tidak lengkap di wilayah kerja Puskesmas Basuki Rahmad Kota Bengkulu. Dampak apabila bayi tidak melalukan imunisasi adalah daya tahan tubuh rendah, mudah terserang virus penyakit. Penelitian ini bertujuan untuk mempelajari hubungan pendidikan dan pekerjaan ibu dengan kelengkapan imunisasi pada bayi di Wilayah Kerja Puskesmas Kota Bengkulu. Penelitian ini menggunakan jenis penelitian Survey Analitik dengan desain Cross Sectional. Populasi dari penelitian ini adalah seluruh ibu yang mempunyai bayi > 9 bulan sampai 18 bulan yang berjumlah 651 bayi. Teknik pengambilan sampel menggunakan teknik Simple Random Sampling yang berjumlah 87 bayi. Pengumpulan data dalam penelitian ini menggunakan data primer dan sekunder dengan teknik analisis data dilakukan dengan analisis univariat dan bivariat dengan menggunakan uji statistik Chi-Square $\left(\chi^{2}\right)$ melalui program SPSS. Hasil penelitian ini didapatkan : diketahui bahwa dari 87 orang ibu yang memiliki bayi, terdapat 66 orang ibu (75,9\%) berpendidikan menengah, 67 orang ibu (77,0\%) yang tidak bekerja, dan 69 orang ibu (79,3\%) yang mempunyai bayi dengan imunisasi lengkap, dan ada hubungan yang signifikan antara tingkat pendidikan dan pekerjaan ibu dengan kelengkapan imunisasi pada bayi di wilayah kerja Puskesmas Basuki Rahmad Kota Bengkulu dengan kategori hubungan sedang. Diharapkan petugas kesehatan untuk melakukan penyuluhan tentang imunisasi dan meningkatkan pelayanan imunisasi pada bayi.
\end{abstract}

Kata Kunci : bayi, kelengkapan imunisasi, pendidikan, pekerjaan 


\begin{abstract}
The background of this study was the incomplete coverage of immunization in working area of Basuki Rahmad Public Health Center Bengkulu. Impacts if baby did not pass immunization were low body resistance and susceptible to viral diseases. This study aimed to study the relationship between education level and maternal work with the completeness of immunization in babies in working area of Basuki Rahmad Public Health Center Bengkulu. This study used Analytical Survey research type with Cross Sectional design. The population of this study were all mothers who had babies > 9 months to 18 months, amounting to 651 babies. The sampling technique used Simple Random Sampling technique which amounts to 87 babies. Data collection in this research used primary and secondary data with data analysis technique done by univariate and bivariat analysis with Chi-Square statistical test $\left(\chi^{2}\right)$ through SPSS program. The results of this study were obtained: it was known that of 87 mothers who had babies, there were 66 mothers (75.9\%) had medium education, 67 mothers (77.0\%) who did not work, and 69 mothers $(79.3 \%$ ) who had babies with complete immunization, and there was a significant relationship between the level of education and the mother's work with the completeness of immunization in babies in working area of Basuki Rahmad Public Health Center Bengkulu with medium relations category. It was expected that health workers to conduct counseling about immunization and improve immunization services in babies.
\end{abstract}

Keywords : baby, completeness of immunization, education, occupation

\section{A. Pendahuluan}

Salah pembangunan

satu

kesehatan

strategi adalah mewujudkan Indonesia sehat.Sebagai acuan dari pembangunan adalah konsep paradigma sehat yaitu pembangunan kesehatan yang memberikan priorotas utama pada upaya pelayanan peningkatan kesehatan promotif dan preventif. Salah satu upaya pencegahan penyakit menular adalah upaya imunisasi (Depkes RI, 2005).

Setiap tahun lebih dari 1,4 juta anak di dunia meninggal karena berbagai penyakit yang sebenarnya dapat dicegah dengan imunisasi. Beberapa penyakit menular yang termasuk kedalam penyakit yang dapat dicegah dengan imunisasi antara lain TBC, Difteri, Tetanus, Hepatitis B, Pertusis, Campak, Polio, Radang selaput otak, dan radang paru-paru. Anak-anak yang telah diberi imunisasi akan terlindung dari berbagai penyakit berbahaya tersebut yang dapat menimbulkan kecacatan dan kematian bayi (Kemenkes RI, 2015).

Imunisasi adalah salah satu cara intervensi yang paling efektif dalam menurunkan angka kesakitan, angka kematian bayi dan balita serta meningkatkan angka harapan hidup (Ranuh, 2008). Menurut world health organization (WHO) imunisasi telah terbukti sebagai salah satu upaya kesehatan masyarakat yang penting.Program imunisasi telah menunjukkan keberhasilan yang sangat luar biasa dan merupakan usaha yang sangat hemat biaya dalam mencegah penyakit menular. WHO telah mencanangkan program ini (Global Programm for Vaccines and Immunization) organisasi pemerintah di seluruh dunia bersama UNICEF, WHO, dan World Bank. Menurut perhitungan Kementerian PPN/Bappenas 2015 
mempunyai target di 2019 yaitu meningkatkan persentasi Kab/Kota yang mencapai $80 \%$ imunisasi dasar lengkap pada bayi dari 7,21\% mencapai $95 \%$, target tersebut untuk menjawab ketimpangan imunisasi dasar antara daerah yang terendah yaitu Papua 47,27\% dan tertinggi di Jambi 99,85\%. Di Indonesia pada tahun 2015 cakupan imunisasi tertinggi adalah di Provinsi Jambi dengan persentase 99,85\% sedangkan yang terendah terletak di Provinsi Papua dengan persentase $47,27 \%$

Indikator cakupan imunisasi harus mencapai di atas $80 \%$ dari seluruh sasaran populasinya.Namun sangat disayangkan cakupan pemberian imunisasi dibeberapa kabupaten di Indonesia masih sangat rendah. Angka ini masih dibawah target Universal Child Immunization (UCI) yaitu, di atas $80 \%$. Sejak penetapan The Exspended program on Imunization (EPI) oleh World Health Organization (WHO), cakupan lima imunisasi dasar lengkap (LIL) yang terdiri dari imunisasi hepatitis, BCG, polio, campak, dan DPT, meningkat dari (5\%) hingga mendekati $(80 \%)$ di seluruh dunia. Sekurang-kurangnya ada 2,7 juta kematian akibat campak, tetanus neonatrum dan pertusis serta 200.000 kelumpuhan akibat polio yang dapat dicegah setiap tahunnya melalui imunisasi. Vaksinisasi terhadap 7 (tujuh) penyakit telah direkomendasikan EPI sebagai imunisasi rutin di negara berkembang yaitu imunisasi BCG (1x), DPT (3x), polio (4x), Campak (1x), dan Hepatitis B (3x).Perkembangan program imunisasi (PPI) di Indonesia dilaksanakan mulai tahun 1979 (Ranuh, 2008).

Kelurahan UCI adalah kelurahan dimana $\geq 80 \%$ dari jumlah bayi yang ada di desa tersebut yang mendapat imunisasi dasar lengkap, persentase kelurahan UCI di Kota Bengkulu tahun 2015 mencapai $82,09 \%$ atau 55 kelurahan dari 67 kelurahan, cakupan ini turun jika dibangdikan dengan tahun 2014 cakupan mencapai $88,1 \%$. Gambaran cakupan kelurahan UCI sebagai berikut : Tahun 2014 yaitu 88,1\%, Tahun 2013 yaitu $82,1 \%$, Tahun 2012 yaitu $82,1 \%$, tahun 2011 yaitu 74,6\%, tahun 2010 yaitu 82,1 (Dinkes kota Bengkulu, 2015).

Berdasarkan penelitian yang dilakukan oleh Azizah et al. (2012) didapatkan hasil penelitian bahwa status kelengkapan imunisasi dipengruhi oleh faktor pengetahuan, motif, pengalaman, pekerjaan, dukungan keluarga, fasilitas Posyandu, lingkungan, sikap, tenaga kesehatan, penghasilan dan pendidikan. Sarimin (2014) menyimpulkan bahwa ada hubungan antara tingkat pendidikan dengan kelengkapan imunisasi pada bayi, dimana di dalam penelitiannya terdapat 33 responden di peroleh ibu yang memiliki pendidikan menengah yaitu sebanyak 18 orang $(54,5 \%)$ dan tingkat pendidikan dasar sebanyak 15 orang $(45,5 \%)$. Tingkat pendidikan akan berpengaruh terhadap prilaku ibu dalam pemberian imunisasi dasar pada bayi. Semakin tinggi tingkat pendidikan seseorang semakin baik juga pengetahuannya dan dengan pengetahuan yang baik tersebut nantinya juga akan berdampak baik pada perilaku ibu dalam pemberian imunisasi dasar pada balita. Peran seorang ibu pada program imunisasi sangatlah penting, karena suatu pemahaman untuk program ini amatlah diperlukan untuk kalangan tersebut. Masalah pengertian dan keikutsertaan orang tua dalam imunisasi tidak akan menjadi halangan yang besar jika pendidikan yang memadai tentang hal 
itu diberikan. Program imunisasi dapat berhasil jika ada usaha yang sungguhsungguh dan berkesinambungan pada orang yang memiliki pengetahuan dan komitmen yang tinggi terhadap imunisasi (Ali, 2003).Bayi dikatakan mendapat imunisasi lengkap adalah bayi yang mendapatkan BCG (1 kali), Polio (4 kali), DPT (3 kali), DPT-HBHib (3 kali), Polio (4 kali), dan Campak (1 kali) (Kemenkes RI, 2015).

Berdasarkan profil Dinas Kesehatan Provinsi Bengkulu tahun 2015 diketahui bahwa cakupan imunisasi tertinggi terdapat di Bengkulu Utara sebesar 115\%, sedangkan cakupan imunisasi terendah adalah Kabupaten Bengkulu Tengah yaitu 4\%. Program imunisasi ini telah diterapkan di masing-masing Puskesmas berdasarkan Kecamatan yang ada di Bengkulu. Diketahui bahwa cakupan imunisasi terendah di Kecamatan Selebar adalah Puskesmas BasukiRahmad sebesar (125,2\%), sedangkan cakupan imunisasi tertinggi di kecamatan selebar adalah Puskesmas Betungan Sebesar (136,5\%) (Dinkes Kota Bengkulu, 2015)

Berdasarkan survei awal yang dilakukan pada bulan Mei 2017, dari 10 Ibu terdapat 5 Ibu yang berpendidikan dasar, 3 ibu yang berpendidikan menengah dan 2 ibu berpendidikan tinggi kemudian 4 ibu yang bekerja bekerja sementara 6 ibu tidak bekerja dan 4 orang melakukan imunisasi lengkap, 6 orang tidak melakukan imunisasi lengkap.

Rumusan masalah dalam penelitian ini adalah "Apakah ada hubungan tingkat pendidikan dan pekerjaan ibu dengan kelengkapan pemberian imunisasi pada bayi di wilayah kerja Puskesmas Basuki Rahmad?Tujuan penelitian ini adalah untuk mengetahui hubungan tingkat pendidikan dan pekerjaan ibu dengan kelengkapan pemberian imunisasi pada bayi di wilayah kerja Puskesmas Basuki Rahmad Kota Bengkulu.

\section{B. Metode Penelitian}

Penelitian ini dilakukan di Puskesmas Basuki Rahmad Kota Bengkulu. Jenis penelitian ini adalah Survei Analitik dengan menggunakan desain penelitian Cross Sectional. Populasi dalam penelitian ini adalah seluruh ibu yang mempunyai bayi $>9$ bulan sampai 18 bulan di wilayah kerja Puskesmas Basuki Rahmad untuk dengan jumlah bayi 651 orang bayi dan jumlah sampel 87 orang bayi. Teknik pengambilan sampel menggunakan Simple Random Sampling. Teknik pengumpulan data menggunakan data primer dan data sekunder. Teknik Analisis data menggunakan analisis univariat dan analisis bivariat. Analisis bivariat dalam penelitian ini dengan menggunakan uji Chi Square $\left(\chi^{2}\right)$ untuk mengetahui keeratan hubungan digunakan uji statistik Contingency Coefficient (C).

\section{Hasil Penelitian \\ 1. Analisis Univariat}

Analisis Univariat bertujuan untuk menggambarkan distribusi frekuensi Pendidikan, pekerjaan ibu dan kelengkapan imunisasi pada bayi di wilayah kerja Puskesmas Basuki Rahmad Kota Bengkulu. 
Tabel 1.

Distribusi Frekuensi Pendidikan di Wilayah Kerja Puskesmas

Basuki Rahmad Kota Bengkulu

\begin{tabular}{clcc}
\hline No & Tingkat Pendidikan & Frekuensi & Persentase (\%) \\
\hline 1 & Pendidikan Dasar & 11 & 12,6 \\
2 & Pendidikan Menengah & 66 & 75,9 \\
3 & Pendidikan Tinggi & 10 & 11,5 \\
& Jumlah & 87 & 100,0 \\
\hline
\end{tabular}

Berdasarkan Tabel 1 dapat ibu(12,6\%) berpendidikan dasar, 66 diketahui dari $87 \mathrm{ibu}$ yang memiliki orang ibu (75,9\%) berpendidikan bayi 9-18 bulan di wilayah kerja menengah dan 10 orang ibu $(11,5)$ Puskesmas Basuki Rahmad Kota berpendidikan tinggi.

Bengkulu, terdapat 11 orang

Tabel 2

Distribusi Frekuensi Pekerjaan Ibu di Wilayah Kerja Puskesmas Kota Bengkulu

\begin{tabular}{|c|c|c|c|}
\hline No & Status Pekerjaan Ibu & Frekuensi & Persentase $(\%)$ \\
\hline 1 & Bekerja & 20 & 23,0 \\
\hline 2 & Tidak bekerja & 67 & 77,0 \\
\hline & Jumlah & 87 & 100,0 \\
\hline
\end{tabular}

Berdasarkan Tabel 2 dapat Bengkulu terdapat 20 orang ibu diketahui dari 87 ibu yang memiliki $(23,0 \%)$ dan 67 orang ibu $(77,0 \%)$ bayi 9-18 bulan di wilayah kerja tidak bekerja.

Puskesmas Basuki Rahmad Kota

Tabel 3

Distribusi Frekuensi Kelengkapan Imunisasi pada Bayi di Wilayah Kerja Puskesmas Basuki Rahmad Kota Bengkulu

\begin{tabular}{|c|c|c|c|}
\hline No & Kelengkapan imunisasi & Frekuensi & Persentase $(\%)$ \\
\hline 1 & Tidak lengkap & 18 & 20,7 \\
\hline 2 & Lengkap & 69 & 79,3 \\
\hline & Jumlah & 87 & 100,0 \\
\hline
\end{tabular}

Berdasarkan Tabel 3 dapat diketahui dari 87 ibu yang memiliki bayi 9-18 bulan di wilayah kerja Puskesmas Basuki Rahmad Kota Bengkulu terdapat 18 orang bayi $(20,7 \%)$ dengan imunisasi tidak lengkap serta 69 orang bayi $(79,3 \%)$ dengan imunisasi lengkap.

\section{Analisis Bivariat}

Analisis Bivariat ini bertujuan untuk mengetahui hubungan antara variabel bebas (pendidikan ibu, pekerjaan) dengan variabel terikat (kelengkapan imunisasi). Hasil analisis bivariat dapat dilihat dari tabel berikut : 
Tabel 4.

Hubungan Tingkat Pendidikan dengan Kelengkapan Imunisasi pada Bayi di Wilayah Kerja Puskesmas Basuki Rahmad Kota Bengkulu

\begin{tabular}{|c|c|c|c|c|c|c|c|c|c|}
\hline \multirow{3}{*}{ Pendidikan } & \multicolumn{4}{|c|}{$\begin{array}{c}\text { Kelengkapan } \\
\text { pemberian } \\
\text { imunisasi }\end{array}$} & \multicolumn{2}{|c|}{ Total } & \multirow{3}{*}{$\chi^{2}$} & \multirow{3}{*}{$\mathrm{p}$} & \multirow{3}{*}{$\mathrm{C}$} \\
\hline & \multicolumn{2}{|c|}{$\begin{array}{c}\text { Tidak } \\
\text { Lengkap }\end{array}$} & \multicolumn{2}{|c|}{ Lengkap } & \multirow{2}{*}{$\mathrm{F}$} & \multirow{2}{*}{$\%$} & & & \\
\hline & $\mathrm{F}$ & $\%$ & $\mathrm{~F}$ & $\%$ & & & & & \\
\hline Dasar & 8 & 72,7 & 3 & 27,3 & 11 & 100,0 & \multirow{4}{*}{22,771} & \multirow{4}{*}{0,000} & \multirow{4}{*}{0,455} \\
\hline Menengah & 7 & 10,6 & 59 & 89,4 & 66 & 100,0 & & & \\
\hline Tinggi & 3 & 30,0 & 7 & 70,0 & 10 & 100,0 & & & \\
\hline Jumlah & 18 & 20,7 & 69 & 79,3 & 87 & 100,0 & & & \\
\hline
\end{tabular}

Berdasarkan Tabel 4 dapat di ketahui bahwa dari 11 orang ibu yang berpendidikan dasar, 8 orang ibu $(72,7 \%)$ mempunyai bayi dengan imunisasi tidak lengkap dan 3 orang ibu $(27,3 \%)$ yang mempunyai bayi dengan imunisasi lengkap. Dari 66 orang ibu bayi dengan pendidikan menengah, terdapat 7 orang ibu $(10,6 \%)$ yang mempunyai bayi dengan imunisasi tidak lengkap dan 59 orang ibu $(89,4 \%)$ yang mempunyai bayi dengan imunisasi lengkap. Dari 10 orang ibu dengan pendidikan tinggi, terdapat 3 orang ibu $(30,0 \%)$ yang mempunyai bayi dengan imunisasi tidak lengkap dan 7 orang ibu $(70,0 \%)$ yang mempunyai bayi dengan imunisasi lengkap.

Untuk mengetahui hubungan tingkat pendidikan dengan kelengkapan pemberian imunisasi pada bayi di Puskesmas Basuki Rahmad Kota Bengkulu dilakukan hasil Chi-Square $\left(\chi^{2}\right)$. Hasil uji statistik Chi-Square di atas diperoleh nilai $\chi^{2}=22,771$ dan asymp.sig $(p)=0,000 . \quad$ Karena asymp.sig $(p)=0,000<0,05$, maka hipotesis nol ditolak, $H_{a}$ diterima. Artinya ada hubungan signifikan antara pendidikan dengan kelengkapan imunisasi di wilayah kerja Puskesmas Basuki Rahmad Kota Bengkulu.

Tabel 5

Hubungan Pekerjaan Ibu dengan Kelengkapan Imunisasi pada Bayi di Wilayah Kerja Puskesmas Basuki Rahmad Kota Bengkulu

\begin{tabular}{|c|c|c|c|c|c|c|c|c|c|}
\hline \multirow{3}{*}{ Pekerjaan } & \multicolumn{4}{|c|}{$\begin{array}{c}\text { Kelengkapan } \\
\text { Pemberian Imunisasi }\end{array}$} & \multicolumn{2}{|c|}{ Total } & \multirow{3}{*}{$\chi^{2}$} & \multirow{3}{*}{$\mathrm{p}$} & \multirow{3}{*}{$\mathrm{C}$} \\
\hline & \multicolumn{2}{|c|}{$\begin{array}{c}\text { Tidak } \\
\text { Lengkap }\end{array}$} & \multicolumn{2}{|c|}{ Lengkap } & \multirow[t]{2}{*}{$\mathrm{F}$} & \multirow[t]{2}{*}{$\%$} & & & \\
\hline & $\mathrm{F}$ & $\%$ & $\mathrm{~F}$ & $\%$ & & & & & \\
\hline Bekerja & 11 & 55,0 & 9 & 45,0 & 20 & 100 & & & \\
\hline Tidak Bekerja & 7 & 10,4 & 60 & 89,6 & 67 & 100 & 18,631 & 0,000 & 0,420 \\
\hline Jumlah & 18 & 20,7 & 69 & 79,3 & 87 & 100 & & & \\
\hline
\end{tabular}

Dari Tabel 5 dapat diketahui bahwa dari 20 orang ibu yang bekerja terdapat 11 orang ibu $(55,0)$ yang mempunyai bayi dengan imunisasi tidak lengkap dan 9 orang ibu $(45,0)$ yang mempunyai bayi dengan 
imunisasi lengkap, sedangkan dari 67 orang ibu yang tidak bekerja terdapat 7 orang ibu $(10,4)$ yang mempunyai bayi dengan imunisasi tidak lengkap dan 60 orang ibu $(89,6)$ yang mempunyai yang mempunyai bayi dengan imunisasi lengkap di wilayah kerja Puskesmas Basuki Rahmad Kota Bengkulu.

Untuk mengetahui hubungan pekerjaan dengan kelengkapan imunisasi pada bayi di wilayah kerja Puskesmas Basuki Rahmad Kota Bengkulu di gunakan uji Chi-Square $\left(\chi^{2}\right)$. Dari hasil uji statistik Chi-Square diperoleh nilai $\chi^{2}=18,631$ dan asymp.sig $\quad(p)==0,000$.Karena asymp.sig $(p)==0,000<0,05$, maka hipotesis nol ditolak, $H_{a}$ diterima.Artinya ada hubungan signifikan antara pekerjaan dengan kelengkapan imunisasi.

\section{Pembahasan}

Berdasarkan hasil penelitian dapat diketahui bahwa dari 11 orang ibu $(12,6 \%)$ yang memiliki bayi dengan pendidikan dasar, 8 orang ibu mempunyai bayi dengan kelengkapan imunisasi tidak lengkap, dan 3 orang ibu yang mempunyai bayi dengan kelengkapan imunisasi lengkap. Dari 66 ibu yang mempunyai bayi yang berpendidikan menengah, terdapat 7 orang ibu dengan kelengkapan pemberian imunisasi tidak lengkap dan terdapat 59 orang ibu bayi dengan kelengkapan pemberian imunisasi lengkap. Dari $10 \mathrm{ibu}$ yang mempunyai bayi dengan status pendidikan tinggi, terdapat 3 orang ibu yang memiliki bayi dengan kelengkapan imunisasi tidak lengkap dan 7 orang ibu yang mempunyai bayi dengan kelengkapan imunisasi lengkap.

Berdasarkan dari hasil penelitian dapat diketahui dari 11 orang ibu $(12,6 \%)$ yang mempunyai bayi dengan pendidikan dasar, terdapat
8 orang ibu yang mempunyai bayi dengan kelengkapan imunisasi tidak lengkap. Hal ini dikarenakan kurangnya kesadaran ibu untuk mengimunisasikan anaknya, kurangnya perhatian dari ibu, ada efek samping dari imunisasi, seperti panas, demam, lebih percaya pendapat teman atau keluarga bahwa tidak imunisasi tidak apa-apa.

Dari 11 orang ibu $(12,6 \%)$ yang berpendidikan dasar, terdapat 3 orang ibu mempunyai bayi dengan imunisasi lengkap. Hal ini dikarenakan meskipun ibu hanya tamatan Sekolah Dasar (SD) dan Sekolah Menengah Pertama (SMP), tetapi ibu bayi sering mengunjungi atau mendatangi penyuluhan dan sering bertanya kepada petugas kesehatan di Pukesmas, jarak Posyandu dari rumah dekat sehingga ibu dengan mudah mengantarkan anaknya untuk melakukan imunisasi,

Dari 66 orang ibu $(75,9 \%)$ yang berpendidikan menengah, terdapat 7 orang ibu yang mempunyai bayi dengan kelengkapan imunisasi tidak lengkap. Hal ini dikarenakan sebagian ibu belum paham pentingnya imunisasi seperti untuk apa imunisasi, apa manfaatnya.

Dari 66 orang ibu $(75,9 \%)$ yang berpendidikan menengah, terdapat 59 orang ibu mempunyai bayi dengan kelengkapan imunisasi lengkap. Hal ini dikarenakan ibu sudah mendapatkan informasi tentang imunisasi, apa yang harus dilakukan dan dari segi biaya, imunisasi sebagai upaya kesehatan masyarakat yang paling hemat biaya

Dari 10 orang ibu $(11,5 \%)$ yang berpendidikan tinggi, terdapat 3 orang ibu mempunyai bayi dengan kelengkapan imunisasi tidak lengkap. Hal ini dikarenakan ibu sibuk bekerja dan bayi hanya dititipkan dengan 
pengasuh sehingga perkembangan anak tidak terawasi dan tidak memiliki kesempatan untuk membawa anaknya ke posyandu untuk imunisasi.

Dari 10 orang ibu $(11,5 \%)$ yang berpendidikan tinggi terdapat 7 orang ibu mempunyai bayi dengan kelengkapan imunisasi lengkap. Hal ini dikarenakan ibu sudah mengerti dampak pada bayi apabila bayi di imunisasi atau tidak di imunisasi secara lengkap.

Berdasarkan hasil Chi-Square menyatakan bahwa ada hubungan signifikan antara pendidikan dengan kelengkapan imunisasi di wilayah kerja Puskesmas Basuki Rahmad Kota Bengkulu artinya semakin tinggi pendidikan ibu maka akan semakin baik juga pengetahuannya dan dengan pengetahuan yang baik tersebut nantinya juga akan berdampak baik pada prilaku ibu dalam pemberian imunisasi dasar pada bayi..

Hal ini sejalan dengan teori Sarimin (2014) bahwa tingkat pendidikan akan berpengaruh terhadap prilaku ibu dalam pemberian imunisasi dasar pada bayi. Semakin tinggi tingkat pendidikan seseorang semakin baik juga pengetahuannya dan dengan pengetahuan yang baik tersebut nantinya juga akan berdampak baik pada prilaku ibu dalam pemberian imunisasi dasar pada bayi. karena itu pihak pemerintah atau Puskesmas perlu untuk menambah pengetahuan orang tua bayi melalui penyuluhanpenyuluhan, penyebaran leaflet, brosur, pemasangan spanduk yang berisikan anjuran agar membawa balitanya ke pelayanan kesehatan untuk diberikan imunisasi.

Berdasarkan hasil penelitian dapat diketahui bahwa dari 20 orang ibu $(23,0 \%)$ dengan status pekerjaan ibu bekerja, terdapat 11 ibu diantaranya memiliki bayi yang mendapatkan imunisasi tidak lengkap, sedangkan 9 ibu lainnya memiliki bayi yang mendapatkan imunisasi secara lengkap sedangkan. Dari 67 ibu yang tidak bekerja, 7 orang ibu yang mempunyai bayi dengan imunisasi tidak lengkap dan 60 orang ibu yang mempunyai bayi dengan imunisasi lengkap di wilayah kerja Puskesmas Basuki Rahmad Kota Bengkulu.

Berdasarkan hasil penelitian dapat diketahui bahwa dari 20 orang ibu $(23,0 \%)$ yang mempunyai bayi dengan status pekerjaan ibu bekerja, terdapat 11 orang ibu yang mempunyai bayi dengan kelengkapan imunisasi tidak lengkap. Hal ini dikarenakan ibu tidak memiliki waktu membawa anaknya ke Posyandu untuk di imunisasi, tuntutan pekerjaan, mengejar karir sehingga mengabaikan kewajiban anak.

Dari 20 orang ibu $(23,0 \%)$ yang mempunyai bayi dengan status pekerjaan ibu bekerja, terdapat 9 orang ibu yang mempunyai bayi dengan kelengkapan imunisasi lengkap. Hal ini disebabkan pekerjaan dapat memberikan kesempatan untuk ibu untuk saling bertukar informasi dan pengalaman sehingga lebih terpapar dengan program-program kesehatan khususnya imunisasi dan banyaknya informasi yang ibu terima dari tempat kerja.

Dari 67 orang ibu $(77,0 \%)$ bayi dengan status pekerjaan ibu tidak bekerja, terdapat 7 orang ibu yang mempunyai bayi dengan kelengkapan imunisasi tidak lengkap. Hal ini di sebabkan jarak yang terlalu jauh dari rumah ke tempat Posyandu, terlalu lama menunggu antrian dan ibu lupa jadwal untuk mengimunisasikan anaknya.

Dari 67 orang ibu $(77,0 \%)$ dengan status pekerjaan ibu yang tidak bekerja terdapat 60 orang ibu yang 
mempunyai bayi dengan kelengkapan imunisasi lengkap. Hal ini disebabkan ibu kesehariannya hanya di rumah jadi memiliki kesempatan yang lebih besar untuk mengimunisasikan anaknya.

Dari hasil uji statistik Chi-Sqaare $\left(\chi^{2}\right)$ menunjukan bahwa Ho di tolak dan Ha diterima yaitu ada hubungan signifikan antara pekerjaan dengan kelengkapan imunisasi pada bayi di wilayah kerja Puskesmas Basuki Rahmad Kota Bengkulu artinya jika ibu bekerja untuk mencari nafkah maka akan berkurang kesempatan waktu dan perhatian untuk membawa bayinya ke tempat pelayanan imunisasi sehingga akan mengakibatkan bayinya tidak mendapatkan pelayanan imunisasi.

Hasil penelitian ini sejalan dengan pendapat Tawi (2005) yang menyatakan bahwa aktifitas ibu yang bekerja akan berpengaruh terhadap waktu yang dimiliki ibu untuk memberikan pelayanan/kasih sayang terhadap anaknya termasuk perhatian ibu pada imunisasi dasar bayinya, tetapi tidak menutup kemungkinan seorang ibu yang bekerja dapat meluangkan waktunya untuk membawa anaknya ke tempat kepelayanan kesehatan untuk melakukan imunisasi.

Ketidaklengkapan imunisasi pada bayi dapat menimbulkan masalah kesehatan, penyebaran masalah tersebut salah satunya dikarenakan oleh status sosial ekonomi pada umumnya dipengaruhi oleh 2 (dua) hal, yaitu a). Terdapat perbedaan kemampuan ekonomis dalam mencegah penyakit atau mendapatkan pelayanan kesehatan, $\quad$ b) Perbedaan sikap hidup dan prilaku hidup yang dimiliki serta pekerjaan yang mempengaruhi sosial ekonomi keluarga sehingga bisa dihubungkan dengan penyebaran masalah kesehatan.

\section{E. Kesimpulan}

1. Dari 87 orang ibu, terdapat 66 orang ibu $(75,9 \%)$ yang berpendidikan menengah di wilayah kerja Puskesmas Basuki Rahmad Kota Bengkulu

2. Dari 87 orang ibu, terdapat 67 orang ibu $(77,0 \%)$ tidak bekerja di wilayah kerja Puskesmas Basuki Rahmad Kota Bengkulu

3. Dari 87 orang ibu, terdapat 69 orang ibu $(79,3 \%)$ yang memiliki bayi dengan imunisasi lengkap di wilayah kerja Puskesmas Basuki Rahmad Kota Bengkulu

4. Ada hubungan yang signifikan antara tingkat pendidikan ibu dengan kelengkapan imunisasi pada bayi di wilayah kerja Puskesmas Basuki Rahmad Kota Bengkulu dengan kategori hubungan sedang.

5. Ada hubunganyang signifikan antara pekerjaan ibu dengan kelengkapan imunisasi pada bayi di wilayah kerja Puskesmas Basuki Rahmad Kota Bengkulu dengan kategori hubungan sedang.

\section{Daftar Pustaka}

Azizah, N, et al. (2012). Faktor-Faktor yang Berhubungan dengan Kelengkapan Imunisasi Dasar pada Bayi Usia 9-11 Bulan di Desa Sumberneja Kec. Mranggen Kab. Demak. Semarang Diakses dari http://jurnal.unimus.ac.id/index. php/jur

bid/article/view/1072/1121 tanggal 25 Mei 2017.

Depkes RI. (2005). Profil Kesehatan Republik Indonesia 2004. Jakarta : Depkes RI.

Dinkes Kota Bengkulu. (2015). Profil Kesehatan Kota Bengkulu 2014. Bengkulu : Dinas Kesehatan Kota. 
Dinkes Provinsi Bengkulu. (2015)

Profil Kesehatan Provinsi

Bengkulu 2014. Bengkulu : Dinas

Kesehatan Provinsi.

Kemenkes RI. (2015). Profil kesehatan indonesia 2014. Jakarta : Kemenkes RI.

Ranuh, I, G, N, (2008). Pedoman Imunisasi di Indonesia Tahun 2008 Edisi Ketiga Cetakan Pertama. Jakarta : Nuha Medika.

Tawi. (2005). Faktor-Faktor yang Mempengaruhi Kelengkapan Pemberian Imunisasi Dasar pada Bayi di Wilayah Kerja Puskesmas Ule Karen. Diakses dari

http://digilib.litbang.depkes.gi.id/ gopada tanggal 26 Mei 2017. 